\title{
ARTIKEL
}

\section{HASHTAG POLITIE}

\section{Hoe politieagenten omgaan met waardeconflicten die ontstaan door sociale media}

\author{
Gjalt de Graaf \& Albert Meijer
}

\begin{abstract}
Sociale media veranderen de samenleving en veroorzaken nieuwe dilemma's in het lokale bestuur. Over de aard van deze conflicten en de wijzen waarop overheidsorganisaties hiermee omgaan, is weinig bekend. Daarom hebben wij empirisch onderzoek gedaan naar de manier waarop politieagenten omgaan met waardeconflicten rondom het gebruik van sociale media. Het onderzoek laat zien dat de bekende conflicten uit de literatuur tussen effectiviteit en efficiency en tussen effectiviteit en rechtmatigheid ook in deze casus dominant waren, maar dat veel meer conflicten dan bekend uit andere studies optraden rondom transparantie en participatie. Verder ontdekten wij dat de biasstrategie vaak werd gebruikt, wat suggereert dat een meer behoudende reactie de voorkeur heeft in een situatie van veel dynamiek. Het onderzoek laat daarmee zien hoe overheidsfunctionarissen omgaan met de spanning tussen een stabiele organisatie en een dynamische omgeving, en juist op dit raakvlak zoeken zij naar passende vormen van coping. In onze aanbevelingen benadrukken we dat het verder versterken van het lerend vermogen van organisaties aandacht verdient, om niet eenmalig de beste omgang met waardeconflicten te vinden, maar juist in staat te zijn steeds een nieuwe omgang te vinden met de nieuwe conflicten die zich voordoen.
\end{abstract}

Relevantie voor practitioners: (a) het gebruik van sociale media leidt tot nieuwe waardeconflicten binnen organisaties en vraagt dus om nieuwe copingstrategieën; (b) er is extra aandacht nodig voor conflicten rondom transparantie en participatie, omdat sociale media juist rondom deze waarden nieuwe conflicten oproepen; (c) het organiseren van lerend vermogen is nodig om de procedures van organisaties voor de omgang met waardeconflicten steeds te herijken.

\section{$1 \quad$ Inleiding}

De samenleving verandert ingrijpend door het gebruik van sociale media (Chew \& Eysenbach, 2010). Dit werd duidelijk bij de 'Facebookrevoluties' in 2009 in Iran en in 2011 in Egypte en Tunesië. De mogelijkheden die sociale media bieden om massaal en decentraal informatie te verspreiden en te delen, hebben gevolgen voor ons openbaar bestuur (Rob, 2012; De Graaf \& Meijer, 2013). Sociale netwerken worden anders en sneller gevormd, netwerken ontstaan plots en snel. Denk aan de rellen in Haren (niet voor niks ook wel Facebookrellen genoemd), die 
alleen mogelijk waren door sociale media. Bij de London Riots van 2011 werden sociale media gebruikt om het plunderen te coördineren (Trottier \& Fucks, 2015). De rellen laten zien dat de lokale politie onvoldoende begrip had van de impact die sociale media kunnen hebben (Briggs, 2012). Ook na de Project X-rellen in Haren werd geconstateerd dat het lokale bestuur onvoldoende zicht had op de impact van sociale media en niet wist hoe te reageren (Commissie Haren, 2013). Gezien de mogelijkheden die sociale media - gerelateerd aan micro-organisatie, framing en onvoorspelbaarheid - bieden om massaal en decentraal informatie te verspreiden en te delen, ontstaan alternatieven voor traditionele manieren van publieke besluitvorming en participatie (Korthagen \& Van Meerkerk, 2014; Bekkers e.a., 2011), en daarmee heeft het massale gebruik van sociale media belangrijke consequenties voor het openbaar bestuur (Rob, 2012; De Graaf \& Meijer, 2013).

Sociale media en sociale netwerken veranderen de samenleving en veroorzaken nieuwe dilemma's in het lokale bestuur, zoals de afweging tussen privacy van burgers en de openbare orde. Conflicten tussen waarden als het beschermen van privacy en het handhaven van de openbare orde zijn niet nieuw, en het lokale bestuur heeft strategieën ontwikkeld voor de omgang met dat soort waardeconflicten, zoals formele procedures en training van medewerkers. Zowel de rellen van Londen als het vandalisme in Haren laten echter zien dat nieuwe vormen van communicatie de interacties binnen samenlevingen en tussen de overheid en burgers veranderen (Bertot e.a., 2010; Bekkers e.a., 2011). Het gebruik van sociale media in de samenleving vormt een uitdaging voor bestaande strategieën voor de omgang met waardeconflicten in het publiek bestuur (Sørensen \& Torfing, 2005). Waardeconflicten zijn inherent aan publiek besturen (De Graaf, 2015) en dat betekent dat de overheid strategieën moet hebben voor de omgang hiermee (Thacher \& Rein, 2004). De London Riots en Project X in Haren hebben duidelijk laten zien dat sociale media ook een impact hebben op de politie. De politie gebruikt zelf sociale media (Meijer \& Thaens, 2013), maar wordt ook geconfronteerd met deze nieuwe vormen van massacommunicatie in de samenleving die invloed hebben op de dagelijkse activiteiten. De rellen in Haren zijn hiervan een voorbeeld, maar ook de recente opwinding over het zoeken naar Anne Faber in Den Dolder, het filmen van de politieaanpak van een zwerver in Rotterdam, het blog van een motoragent over reacties op zijn optreden, et cetera.

Uit de voorbeelden blijkt dat de maatschappelijke interesse in de omgang met deze conflicten groot is. Over de wijze waarop overheidsorganisaties in het algemeen en de politie in het bijzonder omgaan met conflicterende waarden is echter in de academische literatuur zeer weinig bekend. En daarbij geldt tevens dat deze veranderingen een blijvend karakter hebben: de technologische turbulentie zal steeds weer leiden tot nieuwe vragen ten aanzien van de omgang met waardeconflicten. Daarom is het van groot belang dat meer inzicht wordt verkregen in de mogelijkheden voor publieke organisaties om copingstrategieën voor waardeconflicten vorm te geven in een continu veranderende samenleving. 
Deze exploratieve studie bekijkt de impact van sociale media op waardeconflicten in de publieke sector door te focussen op de politie. De centrale vraag is: Welke door sociale media veroorzaakte waardeconflicten worden waargenomen binnen de Nationale Politie, en welke strategieën worden gebruikt om met deze conflicten om te gaan? Deze vragen worden beantwoord door middel van een empirische studie binnen de Nederlandse politie. De resultaten laten zien dat door socialemediagebruik binnen de politie zich in toenemende mate conflicten voordoen rondom de waarden transparantie, rechtmatigheid en participatie. Op basis van ons onderzoek doen we strategische aanbevelingen aan de politie, die zich richten op het vergroten van het vermogen om in een turbulente omgeving een passende omgang te vinden met (snel veranderende) waardeconflicten. ${ }^{1}$

\section{Veranderende waardeconflicten en copingstrategieën door sociale media}

In de literatuur over publieke waarden zijn veel definities te onderscheiden (zie voor een overzicht: Van der Wal, 2008). We definiëren waarden als kwaliteiten van handelingen, dingen, praktijken, mensen en instituties, die gewaardeerd worden omdat ze constitueren, of bijdragen aan wat goed of mooi is, dan wel onze bewondering of lof verdienen (De Graaf, 2016). In de context van het openbaar bestuur hebben we het over publieke waarden. Publieke waarden zijn kwaliteiten van het publiek bestuur. Het concept 'publieke waarden' is de afgelopen jaren een prominente rol gaan spelen in bestuurskundig en organisatiekundig onderzoek (Van der Wal e.a., 2015).

Veelgenoemde publieke waarden in de codes zijn integriteit, effectiviteit, transparantie, efficiëntie, democratie, legitimiteit en rechtmatigheid. Stuk voor stuk waarden waar niemand iets op tegen kan hebben. Maar bij het nastreven van intrinsieke waarden in publieke organisaties blijkt dat ze niet altijd tegelijkertijd gerealiseerd kunnen worden. Ze conflicteren en kunnen zo tot dilemma's leiden. Waarden kunnen niet alleen conflicteren, onverenigbaar zijn, ze blijken ook nogal eens incommensurabel, wat een en ander compliceert. Bij onverenigbare intrinsieke waarden is er geen rationele keuze meer mogelijk. Stephan Lukes omschrijft incommensurabiliteit als volgt: 'There is no single currency or scale on which conflicting values can be measured, and that where a conflict occurs no rationally compelling appeal can be made to some value that will resolve it. Neither is superior to the other, nor are they equal in value' (Lukes, 1989: 125). Incommensurabiliteit betekent niet dat actoren geen keuzes kunnen maken of daar redenen voor kunnen geven, maar dat de redenen die we kunnen geven voor een bepaalde keuze incommensurabel zijn met andere redenen die we zouden kunnen geven bij een andere keuze.

1 Het onderzoek van dit artikel is mogelijk gemaakt door Politie en Wetenschap. Puck van den Brink heeft een grote rol gespeeld bij het verzamelen en analyseren van de empirische data. Eerder hebben de auteurs over dit onderzoek gepubliceerd in Public Administration Review (De Graaf \& Meijer, 2018). Dit artikel is een bewerkte vertaling van deze publicatie. 
In de dagelijkse bestuurspraktijk blijken nastrevenswaardige waarden te conflicteren en moeten keuzes worden gemaakt (Huberts \& Van Hout, 2011; Oldenhof e.a., 2014). De Graaf en Paanakker (2015) vonden bijvoorbeeld dat conflicten tussen rechtmatigheid en transparantie veelvuldig worden gepercipieerd in het openbaar bestuur. Het meest gevonden waardeconflict in een casestudie van een Nederlandse gemeente was die tussen transparantie en effectiviteit (De Graaf e.a., 2016).

Over de politie schrijven Willis en Mastrofski (2016: 38): 'In focusing on what works, police science has tended to focus on only one largely unambiguous value, that of public safety or crime control. This is an important goal of the police, especially in light of its contribution to liberty (Sherman, 2009) but our respondents' comments draw attention to their sensitivity to a much broader array of moral considerations.' In de klassieker Justice without trial (1967) beschrijft Skolnick de dilemma's tussen 'law and order' die politieagenten ervaren. Wat duidelijk wordt in Skolnicks studie is dat politieagenten veel waardeconflicten ervaren in hun werk. Een recentere studie van Maynard-Moody en Musheno (2003) laat ook de alledaagse spanningen en keuzes zien van street-level bureaucraten.

Onderzoek naar conflicterende publieke waarden is juist nu relevant. Brede maatschappelijke ontwikkelingen zoals individualisering, globalisering en IT (Boutellier, 2011) - en sociale media in het bijzonder - hebben een grote invloed op hoe publieke problemen worden opgelost (publiek besturen). De samenleving en publiek besturen worden meer en meer gedifferentieerd (Bevir, 2010), wat tot veranderende en nieuwe waardeconflicten leidt (De Graaf \& Meijer, 2013). Nieuwe strategieën zijn nodig om met de nieuwe conflicten binnen een steeds veranderende context om te gaan. Zo worden burgers steeds vaker bij het openbaar bestuur betrokken. De Nijmeegse politie vond in mei 2013 een mishandelde hond in het kanaal en verspreidde foto's en een oproep via Twitter om de eigenaar te vinden. Buurtbewoners herkenden de eigenaar en gingen direct naar zijn adres om 'verhaal te halen'. Een andere actuele kwestie voor de politie is dat er steeds meer misdaad in cyberspace wordt gepleegd: moet misdaad op de virtuele 'straat' hetzelfde worden behandeld als op de echte straat?

Zoals duidelijk wordt in Lipsky's (1980) klassieke studie, zijn voor publieke actoren waardeconflicten onvermijdelijk, ze zijn een fact of administrative life. Bij beslissingen in het openbaar bestuur spelen vaak diverse en conflicterende waarden een rol. O'Kelly en Dubnick (2005: 394): 'Public administrators are often faced with making difficult choices or judgments among incompatible and incommensurable values.' Wagenaar (1999: 444) concludeerde: '[P]ublic programs are structured in such a way that they regularly confront the administrator with difficult value choices.' Dit is op zichzelf geen probleem, waardeconflicten kunnen tot positieve veranderingen leiden door innovatie en alertheid. Maar er is een gevaar van verlamming door het niet kunnen maken van keuzes. Copingstrategieën (of copingmechanismen, zoals ze ook wel worden genoemd) worden gebruikt om die verlamming te voorkomen en om waardeconflicten hanteerbaar te maken. Lipsky liet bijvoorbeeld zien hoe ambtenaren routines inzetten. Routines voorkomen dat lastige 
keuzes elke keer opnieuw gemaakt moeten worden en maken zo het conflict hanteerbaar.

Over waardeconflicten in het openbaar bestuur schreven Thacher en Rein (2004: 458): 'Based on an examination of practice in crime policy, retirement policy, and refugee policy, we argue that policy actors often do not treat conflicting values as commensurable. Instead, they cope with value conflict by drawing from a repertoire of alternative strategies (...) As we explain throughout, none of these three strategies requires commensurability among values, but each can be a rational response to conflicting public values.' Thacher en Rein laten zien hoe waardeconflicten die niet worden opgelost, kunnen leiden tot psychologische stress en verlamming in het openbaar bestuur. Traditioneel bij waardeconflicten, zo beweren Thacher en Rein, is de zoektocht naar een trade-off. Het archetype van de trade-off is de kosten-batenanalyse: de publieke waarden krijgen een geldelijke waardering en het optimum wordt uitgerekend. Maar zoals Lukes (1996) heeft laten zien, kunnen niet al onze keuzes als trade-offs worden begrepen. Thacher en Rein (2004) hebben een empirisch gefundeerd theoretisch framework ontworpen om te begrijpen hoe publieke actoren omgaan met waardeambiguïteit. Ze claimen dat publieke actoren conflicterende waarden niet als commensurabel beschouwen, en presenteren een repertoire aan strategieën om toch rationeel met conflicten om te kunnen gaan. Het kan gaan om strategieën op individueel en institutioneel niveau. Elke strategie heeft voor- en nadelen. Ze noemen firewalls, een strategie op institutioneel niveau waarbij verschillende organisatieonderdelen of -functies elk voor een van de conflicterende waarden verantwoordelijk worden gehouden, cycling, waarin gedurende een bepaalde periode veel nadruk wordt gelegd op één bepaalde waarde, waarna een tegenbeweging volgt die ervoor zorgt dat er weer aandacht komt voor een andere waarde, en casuïstiek, waarbij actoren een keuze maken per casus op basis van eerdere ervaringen in soortgelijke gevallen. Stewart heeft daar later drie strategieën aan toegevoegd: bias, wat een duidelijke keuze voor één waarde betekent en het negeren van andere, hybridisatie, waarbij de verschillende waarden zo goed en zo kwaad als het gaat toch gecombineerd worden, en incrementalisme, waarin via kleine stapjes meer nadruk wordt gelegd op het belang van één waarde (Smulders e.a., 2014).

Waardeconflicten en copingstrategieën zijn niet statisch, maar veranderen continu onder invloed van processen binnen overheidsorganisaties en in de samenleving. Een belangrijk proces is de digitalisering en het gebruik van sociale media door overheidsorganisaties en in de samenleving. Het gebruik van sociale media heeft grote invloed op de publieke sector omdat communicatie een grote rol speelt in de veelheid aan interacties die er plaatsvinden. Communicatie is van belang in democratische processen, voor beleidsimplementatie, voor het verkrijgen van legitimiteit, om burgers te informeren, voor de agendavorming, voor interne afstemming en nog veel meer. En dit betekent dat veranderingen in het gebruik van communicatiemedia allerlei verschillende gevolgen kunnen hebben. Deze zijn ten dele in kaart gebracht. De implicaties van sociale media voor de politiek zijn redelijk uitvoerig onderzocht (Shirky, 2011; Loader \& Mercea, 2011; 
Loader, 2007) en de instrumentele gevolgen van sociale media voor het publiek bestuur zijn ook bestudeerd (Mergel, 2013; Mossberger e.a., 2013). Verder is er een aantal studies naar het gebruik van sociale media voor bepaalde typen politiewerk, zoals wijkagenten en het bestrijden van misdaad (Crump, 2011; Meijer \& Torenvlied, 2016; Davis e.a., 2014; Beshears, 2017; Meijer \& Thaens, 2013; Grimmelikhuijsen \& Meijer, 2015). Over de gevolgen voor waardeconflicten en gevolgde strategieën is zeer weinig bekend.

\section{Onderzoeksaanpak}

In deze studie is een exploratieve en inductieve onderzoekstrategie toegepast (Eisenhardt, 1989; De Graaf, 2005; Glaser \& Strauss, 1967; De Graaf \& Huberts, 2008). Er is een casestudie binnen de Nederlandse politie uitgevoerd met de focus op de ervaren waardeconflicten veroorzaakt door sociale media en de manieren om ermee om te gaan. Vanwege beperkingen in tijd en geld konden niet alle regio's in de studie worden meegenomen. De Nationale Politie kent sinds 2013 tien regionale eenheden. In deze studie zijn vijf regionale eenheden meegenomen, die samen representatief moeten zijn voor Nederland als geheel: Amsterdam, Rotterdam, Limburg, Noor-Nederland en Noord-Holland. Dat betekent dat de twee grootste steden alsmede kleinere politie-eenheden onderdeel van de studie waren.

De casestudie bestond voornamelijk uit semi-open interviews. De verwachting was dat de ervaren waardeconflicten sterk zouden verschillen tussen de verschillende functies binnen de politie, aangezien de perspectieven op sociale media per functieniveau binnen de politie verschillen (Meijer \& Torenvlied, 2016). Binnen de eenheden is daarom gesproken met respondenten met verschillende functieprofielen; er waren respondenten van strategisch, operationeel en ondersteunend niveau. De interviews zijn gehouden met, onder anderen, regionale chefs, rechercheurs, wijkagenten, communicatieadviseurs, woordvoerders, hoofdagenten, brigadiers en socialemediaprojectleiders. Hierdoor was het mogelijk om verschillen en overeenkomsten te herkennen tussen functielagen en te benoemen welke waardeconflicten wel of niet worden ervaren en hoe hiermee wordt omgegaan. Uiteindelijk zijn er 52 interviews gehouden. De eerste respondenten in elke regio zijn benaderd met hulp van Politie en Wetenschap. Samen met de begeleidingscommissie is een brief opgesteld met uitleg over het onderzoek en het verzoek tot medewerking. Door middel van de sneeuwbalmethode (Boeije, 2010) is het aantal respondenten in elke regio uitgebreid. Tabel 1 toont een overzicht van de gehouden interviews, gecategoriseerd naar bredere functieprofielen.

Uit eerder onderzoek (De Graaf e.a., 2016; Willis \& Mastrofski, 2016) is gebleken dat respondenten niet in waarden denken. In de interviews is daarom eerst de nadruk gelegd op veranderingen met betrekking tot sociale media in het werk. Daarna is gevraagd naar ervaringen: wat ervaart men als lastig, waar komt men dilemma's tegen of kwam men voor keuzes te staan, en wat is de rol die sociale media daarbij spelen? Om een focus op de eerste indrukken die tijdens de inter- 
Tabel 1 Overzicht van interviews en casestudies

\begin{tabular}{|c|c|c|c|c|c|c|}
\hline Niveau & Functieprofiel & $\begin{array}{l}\text { Amster- } \\
\text { dam }\end{array}$ & $\begin{array}{l}\text { Lim- } \\
\text { burg }\end{array}$ & $\begin{array}{l}\text { Noord- } \\
\text { Holland }\end{array}$ & $\begin{array}{l}\text { Noord- } \\
\text { Nederland }\end{array}$ & $\begin{array}{l}\text { Rotter- } \\
\text { dam }\end{array}$ \\
\hline \multirow[t]{3}{*}{ Strategisch } & Chefs & & & & $I$ & 1 \\
\hline & Projectleiders & 2 & I & 1 & 2 & 2 \\
\hline & Coördinatoren & & & 1 & & I \\
\hline \multirow[t]{3}{*}{ Operationeel } & $\begin{array}{l}\text { Recherche (ook } \\
\text { internet en FO) }\end{array}$ & 3 & 1 & 5 & 2 & I \\
\hline & Wijkagenten & 2 & 3 & 3 & I & 2 \\
\hline & Hoofdagenten & 2 & 2 & 1 & & I \\
\hline \multirow[t]{2}{*}{ Ondersteunend } & Communicatie & 2 & I & 2 & 3 & I \\
\hline & Service Centrum & & & & & 2 \\
\hline Totaal & & II & 8 & 13 & 9 & II \\
\hline
\end{tabular}

Tabel 2 De waarden uit de Nederlandse code per aspect van goed bestuur

\begin{tabular}{ll}
\hline Centrale criteria goed bestuur & Waarden Code goed openbaar bestuur \\
\hline Democratisch bestuur & Openheid \\
& Participatie \\
& Verantwoording \\
& Legitimiteit \\
Behoorlijk bestuur & Rechtmatigheid \\
& Behoorlijke contacten met burgers \\
Onkreukbaar bestuur & Integriteit \\
Presterend bestuur & Doelgerichtheid \\
& Doelmatigheid \\
& Professionaliteit \\
\hline
\end{tabular}

views zijn gewekt te voorkomen - dat kan immers een gevaar zijn -, zijn alle interviews opgenomen en volledig uitgeschreven. Dit resulteerde in een enorme hoeveelheid data. Deze data is vervolgens in verschillende stappen geanalyseerd (Schilling, 2006). De interviews zijn gecodeerd in MAXQDA, een hulpmiddel bij tekstanalyse. Alle transcripten zijn doorgenomen met een codeboek, en op basis van de vragen uit de interviews zijn hoofdcodes ontwikkeld. De nadruk lag erop om alle lastige afwegingen/dilemma's die in de cases naar voren waren gekomen, in kaart te brengen. Naarmate de analyse vorderde, zijn er open codes toegevoegd die als subcodes fungeerden. Om te zorgen dat dezelfde codes zijn gebruikt, is er een 'intercoder reliability check' uitgevoerd, wat inhield dat drie onderzoekers dezelfde transcripten met hetzelfde codeboek gecodeerd hebben. Daarna is gecontroleerd of deze voldoende overeenkwamen. Na deze check is een aantal kleine aanpassingen gedaan, zodat de transcripten verder gecodeerd konden worden. 
Als volgende stap in de analyse werd ingezoomd op alle voorkomende dilemma's en geanalyseerd in hoeverre deze met socialemediagebruik te maken hadden. Daarna zijn alle gevonden dilemma's getypeerd als specifieke waardeconflicten. Om aan te sluiten bij eerder onderzoek (De Graaf e.a., 2016) zijn de waardeconflicten getypeerd in de centrale waarden die genoemd worden in de Nederlandse Code goed openbaar bestuur van het Ministerie van Binnenlandse Zaken uit 2013 (zie tabel 2).

Eerst heeft een onderzoeker alle gevonden waardeconflicten getypeerd aan de hand van deze waarden. Daarbij was de definitie van de waarden zoals vermeld in paragraaf 2 leidend. Omdat deze typering altijd subjectief is, zijn de uitkomsten vervolgens voorgelegd aan een tweede onderzoeker. Alle gevallen waar de tweede onderzoeker tot een andere typering kwam, zijn besproken totdat beide onderzoekers tot een consensus kwamen (van belang is verder dat er bij elk aangetroffen waardeconflict aandacht aan de context is gegeven door het conflict te omschrijven). Vervolgens is gekeken welke copingstrategie bij elk waardeconflict werd gehanteerd. Hierbij werd hetzelfde stramien gevolgd als bij de typering van de waardeconflicten. Eerst heeft een onderzoeker - op basis van de informatie uit de casus en de definities van de zes copingstrategieën - de copingstrategie per conflict benoemd. Een tweede onderzoeker heeft vervolgens al deze typeringen doorgenomen. Alle gevallen waar de tweede onderzoeker tot een andere typering kwam, zijn besproken totdat de onderzoekers tot een consensus kwamen.

Om meer te leren over de voor- en nadelen van de copingstrategieën is op 21 juni 2016 een workshop gegeven aan zestien landelijke projectleiders sociale media vanuit de elf (politie-)eenheden. De meeste werkten bij de afdeling politieprofessie (projecten), enkele bij de afdeling communicatie. Op de workshop zijn allereerst de resultaten van het onderzoek tot dan toe gepresenteerd. Daarna zijn de vier meest voorkomende waardeconflicten besproken en verder uitgediept. Centraal stond de vraag welke strategieën het beste gebruikt kunnen worden om de conflicten te hanteren, en wat de voor- en nadelen van de strategieën waren.

\section{Bevindingen}

Eerst beantwoorden we de vraag welke waardeconflicten ontstaan door het gebruik van sociale media door de politie en in de samenleving. Het totaaloverzicht van de cases staat in tabel 3.

Het aantal waardeconflicten dat is gevonden, is groter en veelzijdiger dan in eerder onderzoek van Meijer en Thaens (2013). Daarbij zijn vooral de conflicten tussen effectiviteit en efficiency en tussen effectiviteit en rechtmatigheid sterk aanwezig. Ook de conflicten tussen efficiëntie en participatie en tussen rechtmatigheid en openheid worden in bijna alle regio's genoemd. Deze vier meest aangetroffen waardeconflicten (vet gedrukt in tabel 3) zullen we hieronder in meer 
Tabel 3 Overzicht van alle waardeconflicten van alle vijf casestudies

\begin{tabular}{|c|c|c|c|c|c|c|c|}
\hline & & Regio I & Regio 2 & Regio 3 & Regio 4 & Regio 5 & Totaal \\
\hline I & Effectiviteit versus efficiëntie & 4 & 3 & 5 & 2 & 4 & 18 \\
\hline 2 & $\begin{array}{l}\text { Effectiviteit versus rechtmatig- } \\
\text { heid }\end{array}$ & 3 & $\mathbf{I}$ & $\mathbf{I}$ & 3 & 2 & 10 \\
\hline 3 & Effectiviteit versus integriteit & 1 & I & & & & 2 \\
\hline 4 & Effectiviteit versus openheid & 1 & & & & & I \\
\hline 5 & Effectiviteit versus participatie & & & & 1 & & I \\
\hline 6 & Efficiëntie versus verantwoording & & & I & & & 1 \\
\hline 7 & Efficiëntie versus legitimiteit & & I & & & & I \\
\hline 8 & Efficiëntie versus gelijkheid & & & & I & & I \\
\hline 9 & Efficiëntie versus participatie & 2 & $\mathbf{I}$ & & $\mathbf{I}$ & I & 5 \\
\hline 10 & Openheid versus professionaliteit & 1 & & & & & I \\
\hline II & Openheid versus integriteit & 2 & I & & & & 3 \\
\hline 12 & Rechtmatigheid versus participatie & & & 1 & I & & 2 \\
\hline 13 & Rechtmatigheid versus openheid & & I & $\mathbf{I}$ & $\mathbf{I}$ & 2 & 5 \\
\hline
\end{tabular}

Tabel 4 Overzicht van alle copingstrategieën van alle vijf casestudies

\begin{tabular}{|c|c|c|c|c|c|c|c|}
\hline & & Casus I & Casus 2 & Casus 3 & Casus 4 & Casus 5 & Totaal \\
\hline I & Firewalls & & & & & & 0 \\
\hline 2 & Bias & 4 & 4 & 3 & 4 & 4 & 19 \\
\hline 3 & Casuïstiek & 3 & 2 & & 2 & 2 & 9 \\
\hline 4 & Cycling & I & & 2 & I & I & 4 \\
\hline 5 & $\begin{array}{l}\text { Incrementa- } \\
\text { lisme }\end{array}$ & & 2 & 1 & & 1 & 4 \\
\hline 6 & Hybridisatie & 6 & I & 2 & 2 & 2 & 13 \\
\hline
\end{tabular}

detail bespreken. Tabel 4 laat zien welke copingstrategieën er gehanteerd worden om met bovenstaande conflicten om te gaan.

De tabel laat zien dat bias de dominante copingstrategie is en dat hybridisatie ook veel wordt genoemd. Casuïstiek scoort iets lager en cycling en incrementalisme scoren weer een stuk lager. Opvallend was dat de strategie van de firewall nergens werd aangetroffen. Om deze patronen - zowel de conflicten als de copingstrategieën - nader te duiden zoomen we hieronder in op de belangrijkste conflicten.

\subsection{Effectiviteit versus efficiëntie}

Net zoals het geval was in een eerdere studie naar waardeconflicten in het openbaar bestuur (De Graaf \& Paanakker, 2015), is het meest gepercipieerde conflict in deze casus tussen effectief besturen en efficiënt besturen (streven naar meer effectiviteit betekent vaak meer middelen). De strategie die in het geval van de 
politie hierbij gehanteerd wordt, is bias, met een bias voor efficiëntie; er is simpelweg geen tijd om alle signalen op te pikken die via sociale media worden afgegeven. Sporadisch is ook hybridisatie aangetroffen, met name wanneer het waardeconflict veel aandacht kreeg in de (sociale) media.

Op operationeel niveau komt naar voren dat er enorm veel informatie door sociale media beschikbaar is. Hoe hiermee om te gaan? Hoe moet men bijvoorbeeld omgaan met een zelfmoordaankondiging op sociale media? Er wordt voor één waarde gekozen (bias): efficiëntie; dit gaat ten koste van de effectiviteit, bijvoorbeeld het voorkomen van de zelfmoord. Een kanttekening is dat veel wijkagenten online zijn en hierdoor soms dit soort signalen of meldingen toch oppakken; ze zien dat als hun taak. In dat geval is er sprake van het nastreven van verschillende (conflicterende) waarden (hybridisatie) en is het aan de individuele agent hier zo goed mogelijk mee om te gaan. Het is lastig om als wijkagent op Twitter helemaal niet op meldingen in te gaan. Het ligt dan ook aan de casus of er al dan niet wordt ingegaan op meldingen.

Daarnaast is op operationeel niveau aangetroffen dat er een onderscheid gemaakt kan worden tussen recherche en andere agenten binnen de organisatie. Binnen de recherche is een (klein) deel online actief. Informatie over strafbare feiten komt soms via sociale media naar voren; bijvoorbeeld video's van jongeren die een individu mishandelen of van een vrouw die zwaar mishandeld wordt. Mocht een agent dit soort informatie op straat aantreffen, dan zou er ingegrepen worden; op de digitale straat blijkt dit een stuk lastiger. Er zijn veel van dit soort video's, en vaak wordt er geen aangifte gedaan. Bovendien is op de digitale straat de context veel minder duidelijk. De politieorganisatie legt hier de nadruk op efficiëntie (bias) ten koste van het vervolgen van strafbare feiten (effectiviteit). Er lijkt echter geen duidelijk beleid aan ten grondslag te liggen.

Op strategisch niveau komt naar voren dat video's die op sociale media verschijnen veel impact kunnen hebben op het werk van de politie. De massale aandacht die sociale media met een film kunnen genereren, is enorm en maakt het de politie soms lastig. Een voorbeeld waar burgers voor eigen rechter gingen spelen, was toen er op sociale media beelden werden gedeeld van 'ponypletters'; beelden van grote en zware mensen die op kleine pony's gingen zitten, die vervolgens door het gewicht bezweken. De politie weet niet zo goed hoe in dat proces te interveniëren. Het is op dit moment niet mogelijk om effectief actie te ondernemen; de nadruk binnen dit waardeconflict ligt op efficiëntie (bias): 'DD]e straat is voor een deel gedigitaliseerd. Wij hebben nog niet de vertaling gemaakt (onvoldoende) om op die digitale straat ook gewoon politie te kunnen zijn. Te handhaven, in gesprek te gaan, te controleren. Maar ook dingen te laten zoals ze zijn. Ik zeg ook veel: "de straat is gedigitaliseerd, dus je moet meer blauw online hebben wil je dat werk kunnen blijven doen." Jeugdoverlast is afgenomen, maar ons toezicht is niet vergelijkbaar toegenomen.'

Momenteel zijn bias (ten faveure van efficiëntie) en hybridisatie de meest gebruikte strategieën. Het grote nadeel van bias is dat het ten koste gaat van een andere waarde, in dit geval effectiviteit. Er gebeurt meer en meer in de digitale 
wereld, ook strafbare feiten, en die worden nu nauwelijks aangepakt; er blijft veel liggen (Wall, 2003). Normaal gesproken is het voordeel van bias dat deze duidelijkheid schept. Maar het mede voorkomen van hybridisatie toont aan dat die duidelijkheid er nu niet is. Er is veel onzekerheid over wat wel en wat niet te doen. Dit is het bekende nadeel van bias: ontevredenheid bij de medewerkers. Dat is een belangrijke indicatie om de strategie te heroverwegen. Het vraagt om bewustwording in de organisatie over de invloed van sociale media, en realisatie dat ook dat onderdeel is van het werk; ook daar moet de politie opsporen en handhaven. Zoals deelnemers van de workshop het uitdrukten: 'Het mag geen hobbyisme meer zijn' en 'Nu lijkt het net of je alles kan doen online, zonder consequenties.'

Een en ander kan ook aanleiding zijn om de specifieke opsporing en handhaving op sociale media nader te bekijken. Zo verschilt de etiquette op sociale media met die op straat (een belediging op straat wordt veel eerder opgepakt dan een belediging via Twitter). Wellicht kunnen betere scanmanieren worden ontwikkeld om berichten te filteren, en kan er meer aandacht komen voor het prioriteren en indelen van het (digitale) werkproces. En kunnen specifieke interventies voor de digitale omgeving worden ontwikkeld.

\subsection{Effectiviteit versus rechtmatigheid}

Het conflict tussen rechtmatigheid en effectiviteit is een klassieke voor de politie. In de klassieker Justice without trial (1967) beschreef de criminoloog Skolnick al de dillema's voor politiemensen 'between law and order'. Of denk aan de IRTaffaire. Wat we hier nu zien, is dat sociale media nieuwe dilemma's op dit gebied veroorzaken. De (technologische) ontwikkelingen gaan snel, wet- en regelgeving lopen achter en daar is veel onzekerheid over. Bij dit conflict is een bias voor rechtmatigheid. Juridische kaders lopen vaak achter, en toch zien we in de praktijk een bias voor rechtmatigheid boven effectiviteit. Veel dingen mogen niet, of soms is het onduidelijk wat er wel en niet mag, terwijl het werk effectiever zou kunnen wanneer je de regels zou schenden.

Op strategisch niveau komt er veel naar voren omtrent de wetten en regels die met sociale media in het geding komen of nog ontwikkeld moeten worden. De politie mag een persoon bijvoorbeeld niet zomaar in het openbaar volgen, ook al zou dat aan de effectiviteit bijdragen - een verdachte opsporen bijvoorbeeld. De politie kan niet zonder toestemming van de officier van justitie een Facebookpagina van iemand bekijken. Juridische kaders blijken belangrijk voor de politie en er is dan ook telkens een bias voor de waarde rechtmatigheid. Deze copingstrategie (en de keuze voor rechtmatigheid) zorgt er ook voor dat de hoeveelheid werk voor de politie binnen de perken blijft. Maar de ervaring is dat het ten koste gaat van effectiviteit. Het gaat bovendien vaak om informatie die een burger wel kan raadplegen, wat ook kan leiden tot onbegrip bij burgers.

Op operationeel niveau komt duidelijk naar voren dat de wetgeving ervoor zorgt dat daar waar sociale media mogelijk een rol spelen, bijvoorbeeld bij opsporing, er eerst toestemming moet komen; privacyoverwegingen spelen een belangrijke rol. Het proces van toestemming krijgen kan lang duren en leidt tot achterstanden 
van de politie op ontwikkelingen op sociale media. Toch is bias (voor rechtmatigheid) de gevolgde strategie. Rechtmatigheid botst hier ook met participatie bij opsporing van verdachten. Een citaat: 'Een groot probleem hier, is dat vaak de Telegraaf het weet, het ANP het weet, de journalist het weet, maar de recherche het niet weet omdat er wettelijke drempels in de weg liggen.' Op zowel strategisch als operationeel niveau komt naar voren dat de wetten en regels omtrent sociale media nog onduidelijk zijn, en dit zorgt ervoor dat er een grijs gebied is waarin de politie moet werken. De politie is gewend om met kaders te werken en zo worden er ook veel kaders ontwikkeld voor sociale media. Het lastige is echter dat sociale media continu veranderen en dat regels snel verouderd zijn. Zo blijft het zoeken hoe zo goed mogelijk om te gaan met sociale media.

We zien in de cases een duidelijke bias voor rechtmatigheid. Het daarbij behorende nadeel is dat het ten koste gaat van iets anders, in dit geval van effectiviteit. Net als bij het vorige dilemma zien we dat het traditionele voordeel van bias - duidelijkheid - zich hier niet manifesteert. Dat komt in dit geval niet doordat onduidelijk is dat rechtmatigheid de belangrijkere waarde is van de twee, maar doordat rondom sociale media vaak onduidelijk is wat rechtmatigheid is.

De projectleiders ervaren de nadelen van de huidige strategie als groot en gaan dus op zoek naar andere strategieën. Wel wordt erkend dat er door de snelheid van de technologie altijd een grijs gebied zal zijn. De juridische kaders lopen altijd achter. Het idee leeft echter dat er nog wat te winnen valt door betere voorlichting bij wijkagenten; daar zou nog weinig kennis zijn omtrent sociale media en opsporingsprocedures. Door gebrek aan kennis wordt dit waardeconflict versterkt. Rechtmatigheid begint bij het kennen van de regels, en daar ontbreekt het nogal eens aan. Daarbij moeten niet alleen de juridische kaders worden benadrukt, maar juist ook de juridische mogelijkheden. En zo kunnen de nadelen van de bias voor rechtmatigheid worden verminderd. 'Regels hoeven niet vertragend te zijn, als de juiste route wordt gevolgd.'

Wel kunnen alle procedures nog eens tegen het licht worden gehouden om te kijken of ze gemoderniseerd kunnen worden, en minder vertragend kunnen werken. Toestemming krijgen van de officier van justitie blijft in veel gevallen belangrijk, maar wellicht kan dat op een digitale manier in plaats van via een telefoontje. De verwachting is immers dat door sociale media dit soort verzoeken sterk zullen toenemen en het moet voor de officier van justitie werkbaar blijven.

\subsection{Efficiëntie versus participatie}

Door veel politieambtenaren wordt getwitterd, wat de participatie van de burger bevordert. Het heeft echter ook veel reacties van burgers tot gevolg, waarmee het moeilijk omgaan is. Sommige wijkagenten voelen door sociale media de druk om snel te reageren. De verwachting dat we allemaal altijd online zijn, is een intrinsieke eigenschap van sociale media (Turkle, 2011). Daarom wordt de druk gevoeld alles door te nemen. Zowel op operationeel niveau als ondersteunend niveau doet het conflict tussen participatie en efficiëntie zich voor. 
De meest gehanteerde strategie is hybridisatie; zo goed en zo kwaad als het gaat, proberen veel agenten zowel de participatie van de burger te bevorderen als de tijd en aandacht voor sociale media binnen de perken te houden. Bij hybridisatie moet vervolgens worden gekeken in hoeverre dat lukt; er is immers een conflict. Het gaat vaak ten koste van veel vrije tijd van de agenten. Er wordt tijdens de workshop niet gepleit voor een andere strategie, wel voor het zo goed mogelijk ondervangen van de nadelen. Een gedeelte van de oplossing wordt gezocht in het managen van verwachtingen van de burger. Duidelijk aangeven wanneer je niet beschikbaar bent en niet zal reageren. Daarbij kan bijvoorbeeld worden doorverwezen naar het teamaccount. Ook kan worden gedacht aan het organiseren van back-up als de agent niet aan het werk is.

Ook wordt een strategie geopperd die aan firewalls doet denken: de verantwoordelijkheid delen met meerdere teamleden. Geen persoonlijke accounts meer, maar bijvoorbeeld geografische. Strikt genomen hoeven dit geen firewalls te zijn omdat de individuele agent nog steeds toegang tot het gedeelde account zou kunnen hebben, maar het legt zo wel organisatorisch de verantwoordelijkheid ergens anders neer, waardoor het dilemma voor de individuele agent wordt opgeheven. Maar je kunt ook het idee van firewalls verder doortrekken en socialemediateams creëren, en zo sociale media helemaal weghouden bij individuele agenten. Op deze manier kan ook de participatie via sociale media worden geprofessionaliseerd, en wordt het belang duidelijker door de organisatie erkend, in plaats van alleen op individueel niveau.

\subsection{Rechtmatigheid versus transparantie}

Uit de casestudie blijkt duidelijk dat de politie door sociale media veel controle over de communicatie kwijt is. Er is bij dit conflict een bias voor rechtmatigheid. Op zowel strategisch als operationeel en ondersteunend niveau is het lastig dat waar politieactie door de wet wordt begrensd, het mogelijk is dat op sociale media de zaak wordt besproken en er dus 'met het verhaal vandoor wordt gegaan'. De regie ligt dan niet bij de politie. Privacy kan bijvoorbeeld een reden zijn geen actie te ondernemen. Als die privacy dan wel door burgers wordt geschonden op sociale media, is er weinig begrip bij burgers waarom de politie zich afzijdig houdt. Het kan ook het beeld creëren van een incompetente politie. 'Het is dus lastig om burgers te vriend te houden, het werk goed te doen en zich aan de regels te houden.' In de praktijk is er een bias voor rechtmatigheid. Dit leidt tot fricties met het publiek; het is lastig voor de politieambtenaar om met deze strijd tussen doen wat de burger wil en het volgen van de regels om te gaan.

Bepaalde ontwikkelingen zijn niet tegen te houden. De politie wil nog vaak de regie houden - 'we moeten geen informatie vrijgeven' -, maar soms gaat dat simpelweg niet meer. De politie is dan gedwongen meer open te zijn; snelheid is vaak geboden, mede vanwege de geloofwaardigheid en het imago van de politie. De communicatiemedewerkers lijken zich hiervan bewust te zijn, maar het zit niet in de cultuur van de politieorganisatie. Dat is een cultuur van opsporing, waarin zij gesloten is en geen informatie naar buiten wil brengen. 
Een hybridisatiestrategie lijkt de enige werkbare, een balans tussen snelheid en zorgvuldigheid. Wellicht vergt dat een cultuuromslag in de politieorganisatie als geheel en bewustwording van het beeld dat in de buitenwereld leeft. 'We gaan er niets over zeggen' kan tot imagoschade leiden zodra via sociale media al veel informatie op de digitale straat ligt. Concreet kan worden gedacht aan het zo snel mogelijk delen van de feiten zodra die bekend zijn. Het geven van tussen-updates, waarbij je ook aan kunt geven wat je nog niet weet. Of aangeven dat je zaken vermoedt, maar dat je het nog moet vaststellen. Of aangeven dat je de identiteit hebt vastgesteld, maar dat je om specifieke redenen die niet kunt openbaren; uitleggen dus waarom je iets niet communiceert. En realiseren dat alles wat de burger kan zien, je ook kunt communiceren.

\section{Conclusies}

Onze uitvoerige verkenning van de relatie tussen sociale media en de waardeconflicten waar politieagenten zich mee geconfronteerd zien, laat duidelijk zien dat veel hetzelfde blijft, maar er tegelijkertijd ook nieuwe spanningen en nieuwe vormen van coping optreden. Het empirisch onderzoek liet zien dat de bekende conflicten uit de literatuur tussen effectiviteit en efficiency en tussen effectiviteit en rechtmatigheid ook in deze casus dominant waren, maar dat er ook veel conflicten optraden rondom transparantie en participatie. Het relatief frequente voorkomen van deze conflicten wijkt af van andere studies naar publieke waardeconflicten waarbij niet specifiek werd gekeken naar sociale media (bijvoorbeeld De Graaf e.a., 2016).

Het onderzoek naar de reactiepatronen van agenten - de copingstrategieën - liet zien dat de politie nog sterk zoekende is naar de juiste omgang. Er werd in de casus geen bewijs gevonden voor een firewallstrategie (alhoewel in de gesprekken over het conflict tussen efficiency en participatie wel werd gesuggereerd dat dit hier een goede strategie zou kunnen zijn). De biasstrategie werd wel vaak gevonden en dit suggereert dat een meer behoudende reactie de voorkeur heeft in een situatie van veel dynamiek. Mogelijk speelt hier de behoefte aan vastigheid een rol en speelt deze een grotere rol dan de noodzaak om mee te bewegen met veranderingen.

Goeroes van het informatietijdperk suggereren soms dat de wereld helemaal is veranderd en dat bureaucratische organisaties helemaal niet meer passen bij deze omgeving. Ons onderzoek levert hiervoor echter geen bewijs, maar laat zien hoe patronen geleidelijk veranderen: we zien bepaalde verschuivingen in de waardeconflicten, maar ook continuïteit. Daarnaast zien we dat de copingstrategieën juist ook de stabiliteit benadrukken. Het onderzoek laat zien hoe overheidsfunctionarissen omgaan met de spanning tussen een stabiele organisatie en een dynamische omgeving, en juist op dit raakvlak zoeken zij naar passende vormen van coping. Dit is veel minder spectaculair dan de voorbeelden waarmee we dit artikel begonnen en laat veel meer de 'normal practice' van overheidsorganisaties 
in het tijdperk van sociale media zien dan de bijzondere gevallen die in de media worden belicht.

\section{Aanbevelingen: lerende politie}

De empirische studie heeft laten zien dat de variëteit aan waardeconflicten groot is. Ook hebben we gezien dat er een variëteit aan copingstrategieën wordt gehanteerd, met wisselend succes. En daarbovenop geldt dat de technologische turbulentie niet tijdelijk is maar permanent. De aard en het gebruik van sociale media in de samenleving veranderen continu. Hoe kan de politie omgaan met een dergelijk 'messy' en turbulent vraagstuk? Op basis van ons onderzoek doen we vier aanbevelingen. Deze aanbevelingen zijn gebaseerd op het idee dat het formuleren van een procedurele aanpak van deze conflicten in een messy en turbulente praktijk steeds slechts tijdelijk en partieel kan werken. Tegelijkertijd hebben we in de praktijk gezien dat er veel reflecties zijn en het leervermogen van de politie potentieel groot is. In deze aanbevelingen benadrukken we dat juist het verder versterken van dit lerend vermogen aandacht verdient. We keren ons niet tegen procedures, maar benadrukken hier dat de organisatie steeds bezig moet zijn met de procedures te herijken en gericht op het benutten van leerervaringen in de praktijk.

\subsection{Erken dat er geen eenvoudige oplossing is}

In de politiewereld leidt een probleem vaak tot een procedure of richtlijn. Wanneer eenmaal duidelijk is hoe er in een situatie moet worden gehandeld, is het probleem opgelost. Zo is er ook een richtlijn voor sociale media die allerlei problemen aanstipt en aangeeft hoe agenten hiermee om kunnen gaan. Maar daarmee verdwijnen de waardeconflicten niet waar de politie mee wordt geconfronteerd: deze blijven bestaan en er komen steeds weer nieuwe conflicten bij. In het continu veranderende landschap van sociale media bestaan er echter geen blijvende zekerheden en dus ook geen eenvoudige oplossingen. Door de continue veranderingen in de ontwikkelingen rondom sociale media zal het zo blijven dat de invloed hiervan op verschillende niveaus in de politie te merken is. In plaats van te blijven streven naar pasklare oplossingen kan het helpen om simpelweg te erkennen dat die er misschien niet zullen komen.

\subsection{Blijf op alle niveaus leren}

Meebewegen met een veranderende werkelijkheid; dat klinkt makkelijker dan het is. Dit vraagt om een organisatie die blijft leren: op alle niveaus. We hebben gezien dat in de praktijk op allerlei niveaus reflectie en leerprocessen plaatsvinden, maar dat deze in hoge mate zijn gefragmenteerd. Het vraagt bovendien om communicatie tussen verschillende niveaus. Wanneer verschillende niveaus in de politie contact houden, ontstaat er ruimte voor een gezamenlijk leerproces. Immers: veel conflicten zullen herkenbaar zijn voor alle niveaus. Tegelijkertijd blijkt dat er verschillende strategieën worden gehanteerd op het strategische, operationele en ondersteunende niveau. Onderling contact kan het leren in de 
organisatie bevorderen, zowel om te leren van elkaars oplossingen als om samen meer te leren over de verschillende trends en ontwikkelingen rondom sociale media in de politie.

\subsection{Neem actief deel aan het publieke debat}

De legitimiteit van politiewerk wordt mede bepaald in het publieke debat. De politie is niet de enige stem in het publieke debat, ook burgers en media mengen zich hierin. De beeldvorming van het politiewerk komt dan ook niet alleen tot stand door wat de politie zelf zegt, maar ook door wat er óver de politie wordt gezegd. Neem bijvoorbeeld de twitterende wijkagent, veel mensen uiten hun mening hierover online. De politie hoeft zich in dit soort discussies zeker niet afzijdig te houden. Het vertrouwen van burgers in de politie wordt juist beïnvloed door de positie die zij inneemt ten opzichte van andere gebruikers van sociale media, andere media en ook de politiek. Afhankelijkheid van wat anderen over de politie zeggen, is onderdeel van de beeldvorming.

Ook is het handig om de strategie of manier van communiceren te verspreiden naar burgers, zodat zij weten wat ze kunnen verwachten van de politie. Nu verwachten burgers bijvoorbeeld zowel meteen een reactie als zo volledig mogelijke informatie, zoals een openbare organisatie dat zou moeten doen. Dit is bij de politie in veel gevallen niet mogelijk en daarvoor moet een strategie worden gecommuniceerd, zowel intern als extern, omdat dit - door verkeerde verwachtingen tot onrust bij burgers kan zorgen. En dit geldt natuurlijk ook voor allerlei andere conflicten: heldere communicatie met burgers over wat de politie wel en niet kan met sociale media kan het begrip vergroten.

\subsection{Creëer alleen dynamische kaders}

Uit interviews blijkt vaak dat men bij de politie behoefte heeft aan houvast via kaders en regelgeving. Toch is het belangrijk om niet te veel toe te geven aan de verleiding om stevige kaders te geven. Immers: daarvoor is het werkveld met sociale media veel te dynamisch geworden. Hierdoor zal bijna elk kader tekortschieten, snel achterhaald zijn, of verzanden in betekenisloze abstractie. Maar belangrijker nog: strenge kaders geven het signaal af dat houvast mogelijk is. Zoals dit onderzoek laat zien, zorgt houvast er vooral voor dat men (tijdelijk) succesvol is in sommige opzichten, maar tekortschiet in andere. Sociale media veranderen continu en er ontstaan dus ook steeds nieuwe waardeconflicten. Pas daarom regelmatig strategieën aan op de verschillende incidenten, zodat ze ad hoc aansluiten op ontwikkelingen in de maatschappij.

Bovendien valt te verwachten dat er ook altijd buiten de lijntjes gekleurd zal worden. Er is dan ook veel vertrouwen nodig in het individu dat zelf per case kan inschatten hoe om te gaan met sociale media. Met juridische kaders zal wel beter zichtbaar worden wat de politie wel en niet kan en moet doen via sociale media. Deze zijn nu niet eenduidig. Dit is in ontwikkeling, maar zorgt voor veel vragen binnen de organisatie. De vraag is echter of deze eenduidige kaders wel ooit gaan ontstaan, want de technologische dynamiek blijft veel sneller gaan dan de juridi- 
sche reactie hierop. Natuurlijk vormen de juridische kaders belangrijke ijkpunten, maar de verwachting is dat deze tekort zullen blijven schieten.

\section{Literatuur}

Bekkers, V.J.J.M., R. Moody \& A.R. Edwards, 'Micro-mobilization, social media and coping strategies. Some Dutch cases', Policy \& Internet, 2011/4, p. 1-29.

Bertot, J.C., P.T. Jaeger \& J.M. Grimes, 'Using ICTs to create a culture of transparency. E-government and social media as openness and anti-corruption tools for societies', Government Information Quarterly, 2010/3, p. 264-271.

Beshears, M.L., 'Effectiveness of police social media use', American Journal of Criminal Justice, 2017/3, p. 489-501.

Bevir, M., Democratic governance, Princeton, NJ: 2010.

Boeije, H., Analysis in qualitative research, Londen: 2010.

Boutellier, H., De improvisatiemaatschappij. Over de sociale ordening van een onbegrensde wereld, Den Haag: 2011.

Briggs, D., The English riots of 2011. A summer of discontent, Hook: 2012.

Chew, C. \& G. Eysenbach, 'Pandemics in the age of Twitter. Content analysis of tweets during the 2009 H1N1 outbreak', Plos One, 2010/11, p. 1-13.

Commissie Haren, Twee werelden. You only live once, Hoofdrapport Commissie 'Project X' Haren (onder voorzitterschap van Job Cohen), Haren: 2013.

Crump, J., 'What are the police doing on Twitter? Social media, the police and the public', Policy \& Internet, 2011/4, p. 1-27.

Davis, E.F., A.A. Alves \& D.A. Sklansky, 'Social media and police leadership. Lessons from Boston', Australian Policing, 2014/1, p. 10-16.

Eisenhardt, K., 'Building theories from case study research', Academy of Management Review, 1989/4, p. 532-550.

Glaser, B.G. \& A.L. Strauss, The discovery of grounded theory. Strategies for qualitative research, New York: 1967.

Graaf, G. de, 'Het beeld van diergeneeskunde studenten van hun toekomstige patiënten en klanten en professionele verantwoordelijkheid', Tijdschrift voor Diergeneeskunde, 2005/21, p. 654-659.

Graaf, G. de, 'The bright future of value pluralism in public administration', Administration \& Society, 2015/9, p. 1094-1102.

Graaf, G. de, Conflicterende waarden in academia, oratie Vrije Universiteit Amsterdam, Amsterdam: 2016.

Graaf, G. de \& L.W.J.C. Huberts, 'Portraying the nature of corruption. Using an explorative case-study design', Public Administration Review, 2008/4, p. 640-653.

Graaf, G. de \& A.J. Meijer, 'De nieuwe netwerksamenleving en openbaar bestuur. Wat Landsmeer ons leert over onze bestuurlijke toekomst', Bestuurskunde, 2013/1, p. 101-106.

Graaf, G. de \& A.J. Meijer, 'Social media and value conflicts. An explorative study of the Dutch police', Public Administration Review, 2018 (early view: doi: https://doi.org/10. 1111/puar.12914).

Graaf, G. de \& H.L. Paanakker, 'Good governance. Performance values and procedural values in conflict', American Review of Public Administration, 2015/6, p. 635-652.

Graaf, G. de, L.W.J.C. Huberts \& R. Smulders, 'Coping with public value conflicts', Administration \& Society, 2016/9, p. 1101-1127. 
Grimmelikhuijsen, S.G. \& A.J. Meijer, 'Does Twitter increase perceived police legitimacy', Public Administration Review, 2015/4, p. 598-607.

Huberts, L.W.J.C. \& E.J.T. van Hout, 'Goed bestuur. Kiezen of delen?', Bestuurskunde, 2011/2, p. 53-62.

Korthagen, I.A. \& I.F. van Meerkerk, 'The effects of media and their logic on legitimacy sources within local governance networks. A three-case comparative study', Local Government Studies, 2014/5, p. 705-728.

Lipsky, M., Street-level bureaucracy. Dilemmas of the individual in public services, New York: 1980.

Loader, B. (ed.), Young citizens in the digital age. Political engagement, young people and new media, Londen: 2007.

Loader, B. \& D. Mercea, 'Networking democracy? Social media innovations in participatory politics', Information, Communication and Society, 2011/6, p. 757-769.

Lukes, S., 'Making sense of moral conflict', N.L. Rosenblum (ed.), Liberalism and the moral life, Cambridge, MA: 1989, p. 127-142.

Lukes, S., 'On trade-offs between values', F. Farina, F. Hahn \& S. Vannucci (eds.), Ethics, rationality and economic behaviour, Oxford: 1996, p. 36-49.

Maynard-Moody, S. \& M. Musheno, Cops, teachers, counselors. Stories from the front lines of public service, Ann Arbor, MI: 2003.

Meijer, A.J. \& M. Thaens, 'Social media strategies. Understanding the differences between North American police departments', Government Information Quarterly, 2013/4, p. 343-350.

Meijer, A.J. \& R. Torenvlied, 'Social media and the new organization of government communications. An empirical analysis of Twitter usage by the Dutch police', American Review of Public Administration, 2016/2, p. 143-161.

Mergel, I., 'Social media adoption and resulting tactics in the US federal government', Government Information Quarterly, 2013/2, p. 123-130.

Mossberger, K., Y. Wu \& J. Crawford, 'Connecting citizens and local governments? Social media and interactivity in major US cities', Government Information Quarterly, 2013/4, p. 351-358.

O’Kelly, C. \& M.J. Dubnick, ‘Taking tough choices seriously. Public administration and individual moral agency', Journal of Public Administration Research and Theory, 2005/3, p. 393-415.

Oldenhof, L., J. Postma \& K. Putters, 'On justification work. How compromising enables public managers to deal with conflicting values', Public Administration Review, 2014/1, p. 52-63.

Rob, In gesprek of verkeerd verbonden? Kansen en risico's van sociale media in de representatieve democratie, Raad voor het openbaar bestuur, Den Haag: 2012.

Schilling, J., 'On the pragmatics of qualitative assessment', European Journal of Psychological Assessment, 2006/1, p. 28-37.

Sherman, L.W., 'Evidence and liberty. The promise of experimental criminology', Criminology and Criminal Justice, 2009/1, p. 5-28.

Shirky, C., 'The political power of social media. Technology, the public sphere, and political change', Foreign Affairs, 2011/1, p. 28-41.

Skolnick, J.H., Justice without trial. Law enforcement in democratic society, New York: 1967.

Smulders, R., G. de Graaf \& L.W.J.C. Huberts, 'De zoektocht naar goed bestuur. Een analyse van botsende waarden in de publieke sector', Bestuurswetenschappen, 2014/2, p. 47-67.

Sørensen, E. \& J. Torfing, 'The democratic anchorage of government networks', Scandinavian Political Studies, 2005/3, p. 195-218. 
Thacher, D. \& R. Rein, 'Managing value conflict in public policy', Governance, 2004/4, p. $457-486$.

Trottier, D. \& C. Fucks, Social media, politics and the state. Protests, revolutions, riots, crime and policing in the age of Facebook, Twitter and YouTube, New York: 2015.

Turkle, S., Alone together. Why we expect more from technology and less from ourselves, New York: 2011.

Wagenaar, H., 'Value pluralism in public administration', Administrative Theory \& Praxis, 1999/4, p. 441-449.

Wal, Z. van der, Value solidity. Differences, similarities and conflicts between the organizational values of government and business, proefschrift Vrije Universiteit Amsterdam, Amsterdam: 2008.

Wal, Z. van der, T. Nabatchi \& G. de Graaf, 'From galaxies to universe: a cross-disciplinary review and analysis of public values. Publications from 1969 to 2012', American Review of Public Administration, 2015/1, p. 13-28.

Wall, D.S. (ed.), Crime and the Internet, Londen: 2003.

Willis, J.J. \& S.D. Mastrofski, 'Improving policing by integrating craft and science. What can patrol officers teach us about good police work?', Policing and Society, 2016/1, p. 27-44. 